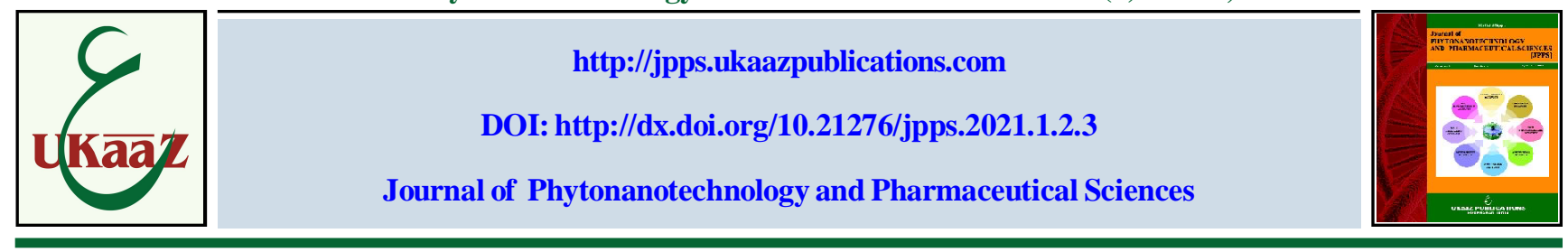

Review Article : Open Access

\title{
Crop improvement via nanotechnology: An overview
}

\section{Saidaiah Pidigam» and Geetha Amarapalli*}

Department of Genetics and Plant Breeding, College of Horticulture, Sri Konda Laxman Telangana State Horticultural University, Rajendranagar, Hyderabad-500 030, Telangana, India

*Department of Crop Physiology, College of Agriculture, Professor Jayashankar Telangana State Agricultural University, Hyderabad-500 030, Telangana, India

\begin{tabular}{|c|c|}
\hline Article Info & Abstract \\
\hline $\begin{array}{l}\text { Article history } \\
\text { Received } 7 \text { April } 2021 \\
\text { Revised } 9 \text { May } 2021 \\
\text { Accepted } 10 \text { May } 2021 \\
\text { Published Online } 30 \text { June } 2021\end{array}$ & $\begin{array}{l}\text { Nanomaterials with their versatile properties are of interest in plant science as vehicles biomolecules in } \\
\text { plants, genetic engineering and, thereby enhance crop productivity. Speed editing protocols by incorporating } \\
\text { nanomaterial is under progress. Nanotechnology (NT) assisted crop breeding is a new strategy and it can be } \\
\text { potentially extended to other plants. It is simple with quick method for editing plant genomes, in addition } \\
\text { to cost effectiveness. It takes a pivotal role in vivid crop breeding plans to enhance the yield and quality }\end{array}$ \\
\hline $\begin{array}{l}\text { Keywords } \\
\text { Nanotechnology } \\
\text { Smart sensors } \\
\text { Crop improvement } \\
\text { Speed breeding } \\
\text { Gene editing }\end{array}$ & exploited in a big way. \\
\hline
\end{tabular}

\section{Introduction}

Nanomaterials have unique physicochemical properties and hence, the field of nanotechnology is gaining an increased interest in plant science, with potential for the application of nanomaterials as vehicles biomolecules in plants, and thereby enhance crop productivity (Khan et al., 2017), and crop improvement (War et al., 2020).

As per ASTM standards, nanomaterials abbreviated as NMs are the natural material or manufactured ones with size of 1 and $100 \mathrm{~nm}$ (ASTM, 2012). They have high surface-to-volume ratio, having chemical and physical properties as compared to their bulk counterparts, suiting them to various fields (Roduner, 2006; Jeevanandam et al., 2018). Recent advances have certain applications in plant growth, productivity enhancement as per Wang et al. (2016). In view of costly and hazardous traditional chemicals, polymeric nanomaterials due to their biocompatibility, synthesis at low-cost and prompt response ability to external stimuli (Baskar et al., 2018) made them attentive. Core/Shell NPs and choice of the shell of the NPs depends on the kind of application (Ghosh Chaudhuri and Paria, 2012). Earlier reviewers reported on biocompatibility of the NPs (Nath et al., 2008), nanostructured shell (Torney et al., 2007), nanogels (Molina et al., 2015) and their classification (Molina et al., 2015) as well. NT has smart applications in plant sciences and agricultural science, but to be exploited in a big way (Wang et al., 2016). Keeping the above in view, an over view is attempted to update the present

Corresponding author: Dr. Pidigam Saidaiah

Associate Professor, Department of Genetics and Plant Breeding, College of Horticulture, Sri Konda Laxman Telangana State Horticultural University, Mojerla-509 382, Telangana, India E-mail: saidu_genetics@yahoo.co.in;drpidigam@gmail.com Tel.: +91-7780509322

Copyright () 2021 Ukaaz Publications. All rights reserved.

Email: ukaaz@yahoo.com; Website: www.ukaazpublications.com happenings in respect of application of nanotechnology in crop improvement.

\section{Applications}

\subsection{Applications in biosensors}

NMs act as "sensing materials" and had practical applications in crop biotechnology (Chaudhry et al., 2018). Different categories of nanosensor types such as plasmonic nanosensors, fluorescence resonance energy transfer (FRET) based nanosensors, carbon-based electrochemical nanosensors, nanowire nanosensors and antibody nanosensors were verified for their applications in biotechnology. Application of nanosensors in plants is at nascent stage (Rai et al., 2012). Their use for detection and quantification of plant metabolic flux, viral and fungal pathogens (Table 1) is proposed. In onion, fabrication of a fluorometric optical onion membrane-based sensor for detection of sucrose based on the synthesis of invertase-nanogold clusters embedded in plant membranes (Bagal-Kestwal et al., 2015) is reported.

\subsection{Application of nanomaterial in plant genetic engineering}

Silicon Carbide-Mediated transformation used to deliver DNA in different calli of tobacco, maize, rice, soybean and cotton (Asad and Arsh, 2012; Lau et al., 2017) and helped to overcome the cell wall barriers in old plants (Table 2).

The dsRNA of different plant viruses can be loaded on non-toxic, degradable, layered double hydroxide. The dsRNAs and/or their RNA breakdown products provide protection against the Cauliflower Mosaic Virus in sprayed leaves. This provides a proof of concept for species-independent and $\mathrm{p}$ assive, without transgene integration into plant cells. 
Table 1: Some nanomaterial used as biosensors in plant experiments and their effects

\begin{tabular}{|c|c|c|c|}
\hline Nanomaterial & Function & Plant used for the experiment & Reference \\
\hline $\begin{array}{l}\text { Single-walled carbon } \\
\text { nanotubes }\end{array}$ & $\begin{array}{l}\text { Near-infrared fluorescence } \\
\text { monitoring of nitric oxide }\end{array}$ & A. thaliana & Giraldo et al., 2014, 2019 \\
\hline $\begin{array}{l}\text { FRET probes with } \\
\text { polystyrene NPs }\end{array}$ & $\begin{array}{l}\text { Phytoalexins quantification } \\
\text { and recognition }\end{array}$ & & Dumbrepatil et al., 2010 \\
\hline NM biosensors & $\begin{array}{l}\text { Microbes rapid detection, } \\
\text { precise quantification }\end{array}$ & Plants & Duhan et al., 2017 \\
\hline $\begin{array}{l}\text { Fluorescent silica NPs } \\
\text { along with antibody }\end{array}$ & Bacterial spot disease & Solanaceae plants & Yao et al., 2009 \\
\hline $\begin{array}{l}\text { DNA biochemical labels } \\
\text { on carbon electrodes }\end{array}$ & $\begin{array}{l}\text { Detection of Pseudomonas } \\
\text { syringae }\end{array}$ & A. thaliana & Lau et al., 2017. \\
\hline Au NPs & $\begin{array}{l}\text { Diagnosis of the phytoplasma } \\
\text { of flavescence dorée disease }\end{array}$ & Grapevine & Firrao et al., 2005. \\
\hline Various smart nanosensors & Mycotoxin detection & Oat, Corn, Barley and Wheat & $\begin{array}{l}\text { Lattanzio and } \\
\text { Nivarlet, } 2017\end{array}$ \\
\hline
\end{tabular}

Table 2: Some nanomaterial used in plant genetic engineering

\begin{tabular}{|l|l|l|l|l|}
\hline Nonmaterial & Function & $\begin{array}{l}\text { Plant used for } \\
\text { the experiment }\end{array}$ & $\begin{array}{l}\text { Nature of } \\
\text { experiment }\end{array}$ & Beference \\
\hline $\begin{array}{l}\text { Clay nanosheets or } \\
\text { bioclay }\end{array}$ & $\begin{array}{l}\text { Mode of delivery } \\
\text { of genetic material }\end{array}$ & Tobacco & Genome editing & Mitter et al., 2017 \\
\hline $\begin{array}{l}\text { Mesoporous silica } \\
\text { nanoparticles (MSNs) }\end{array}$ & $\begin{array}{l}\text { Delivery of Cre } \\
\text { recombinase } \\
\text { carrying loxP sites } \\
\text { integrated into } \\
\text { chromosomal DNA }\end{array}$ & Maize 2013 \\
\hline Carbon nanotubes & DNA delivery & Cotton & Genetic transformation & Zhao et al., 2017 \\
\hline Carbon nanotubes & Deliver DNA, siRNA & $\begin{array}{l}\text { N.benthamiana, wheat, } \\
\text { cotton leaves }\end{array}$ & DNA delivery & Demirer et al., 2018 \\
\hline
\end{tabular}

Table 3: Use of engineered nonmaterial's in plant experiments

\begin{tabular}{|l|l|l|}
\hline Form of the nanoparticle & Reported function & Crop \\
\hline Gold & Reductions in biomass and transpiration rates & Cucurbita pepo \\
\hline Gold & Reduced biomass and transpiration & Pumpkin \\
\hline Cadmium & Root growth & Carrot, cucumber, tomato \\
\hline $\mathrm{TiO}_{2}$ & Increase in nitrate reeducates. & Soybean \\
\hline Graphene & The root hair growth decreased. & Red spinach and cabbage \\
\hline Graphene & Modifications in gene expression & Fruits, leaves, and roots \\
\hline MWCNTs & Creation of new pores and water uptake & Tomato seedlings \\
\hline MWCNTs & Seed germination and root elongation & Zucchini species \\
\hline SWCNTs & Increased its widespread, dispensability, and water column stability & - \\
\hline Carbon nanotubes & Improve root growth & Cucumbers, onions \\
\hline Carbon nanotubes & Diminish root growth & Tomato plants \\
\hline Fullerol & Apoplectic mode of transport in the plant tissues & - \\
\hline
\end{tabular}




\subsection{Use of engineered nanomaterials}

Engineered nanomaterials research and development, in agricultural applications, probably facilitated and framed the next stage of development of genetically modified crops (GMCs), animal production input, biocides, and precision farming system.

Various engineered nanoparticles such as fullerene, fullerol small size and hydrophobicity properties, carbon nanotubes (single or multiple layers of carbons established in a cylinder), gold $(\mathrm{Au}), \mathrm{TiO}_{2}$ (small size $(<5 \mathrm{~nm})$, MWCNTs (Multiwall carbon nanotubes) with 1 $\mathrm{mm}$ long and $20 \mathrm{~nm}$ in diameter and graphene (two dimensional crystalline allotrope of carbon) have applications in crop improvement (Table 3).

\subsection{Application of nanobiotechnology for crop improvement}

CRISPR was used under speed editing strategies by incorporating NMs to combine with speed breeding. Nanotechnology is useful to their double-stranded RNA efficacy for plant improvement (Hofmann et al., 2020). NMs used for grafting can be useful to deliver molecules to GE (Wang et al., 2019). Demirer et al. (2019) devised a tool for the species-independent, targeted, and passive delivery of genetic materials into plant cells without transgene integration. Efficient DNA delivery and strong transient protein expression were achieved in Eruca sativa and T. aestivum leaves and protoplasts. Demirer et al. (2019) demonstrated a second NP-based strategy in which low interfering RNA is delivered to mature Nicotiana benthamiana leaves to silence a gene. NPs can potentially deliver gene-editing cargos to any plant cells and meristematic cells (Sanzari et al., 2019; Wang et al., 2020).

The delivery of GE reagents via NPs into meristematic cells can potentially generate chimerically edited plants. The Cas9/gRNAs produced via this method successfully edited target genes (Doyle $e t$ al., 2019).

Table 4: Steps in speed breeding

\begin{tabular}{|c|l|}
\hline Step 1 & Selection of candidate(s) \\
\hline Step 2 & $\begin{array}{l}\text { Delivery of genetic materials using a different type of } \\
\text { nanotubes }\end{array}$ \\
\hline Step 3 & $\mathrm{~T}_{0}$-generation of seed \\
\hline
\end{tabular}

The speed breeding methods (Table 4) improves the rapid growth of various agricultural crops such as oat, various Brassica species, chickpea, pea and grass pea.

\section{Conclusion}

Nanotechnology based crop breeding is a new strategy. It is simple with quick method for editing plant genomes, in addition to cost effectiveness. It takes a pivotal role in vivid crop breeding plans to enhance the yield and quality enhancement. It can be potentially extended to other plants.

\section{Funding}

The present research did not receive any specific grant from funding agencies in the public, commercial, or not-for-profit sectors.

\section{Acknowledgments}

The authors acknowledge the research workers in the area of nanotechnology, who are applying it for the crop improvement

\section{Conflicts of interest}

The authors declare that there are no conflicts of interest relevant to this article

\section{References}

Asad, S. and Arsh, M. (2012). Silicon carbide whisker-mediated plant transformation, in properties and applications of silicon carbide, Ed. Gerhardt R., pp:1-16.

ASTM (2012). Tandard terminology related to nanotechnology, 6:5-6.

Bagal-Kestwal, D.; Kestwal, R. M. and Chiang, B. H. (2015). Invertase-nanogold clusters decorated plant membranes for fluorescence-based sucrose sensor. J. Nanobiotechnol., 13:30.

Baskar, V.; Meeran, S.; Shabeer, S.T.K.; Subramani, S. and Ali, J. (2018). Historic review on modern herbal nanogel formulation and delivery methods. Int. J. Pharm. Pharm. Sci., 10:1-10.

Chaudhry, N.; Dwivedi S.; Chaudhry V.; Singh A.; Saquib Q. and Azam A. (2018). Bio-inspired nanomaterials in agriculture and food: Current status, foreseen applications and challenges. Microb. Pathog., 123:196-200.

Demirer, G.S.; Zhang, H.; Matos, J.; Goh, N.; Cunningham, F.J. and Sung, Y. (2018). High aspect ratio nanomaterials enable delivery of functional genetic material without DNA integration in mature plants. Bio Rev., 10:1-32.

Demirer, G.S.; Zhang, H.; Matos, J.L.; Goh, N.S.; Cunningham, F.J. and Sung, Y. (2019). High aspect ratio nanomaterials enable delivery of functional genetic material without DNA integration in mature plants. Nat. Nanotechnol., 14:456-464.

Doyle, C.; Higginbottom, K.; Swift, T.A.; Winfield, M.; Bellas, C. and Benito Alifonso, D. (2019). A simple method for spray on gene editing in planta. Bio. Rev., DOI: $10.1101 / 805036$

Duhan, J.S.; Kumar, R.; Kumar, N.; Kaur, P.; Nehra, K. and Duhan, S. (2017). Nanotechnology: The new perspective in precision agriculture. Biotechnol. Rep., 15:11-23.

Dumbrepatil, A.B.; Lee, S.G.; Chung, S.J.; Lee, M.G.; Park, B.C. and Kim, T.J. (2010). Development of a nanoparticle-based FRET sensor for ultrasensitive detection of phytoestrogen compounds. Analyst., 135: 2879-2886.

Firrao, G.; Moretti, M.; Ruiz Rosquete, M.; Gobbi, E. and Locci, R. (2005). Nanobiotransducer for detecting flavescence dorée phytoplasma. J. Plant Pathol., 87:101-107.

Ghosh Chaudhuri, R. and Paria, S. (2012). Core/shell nanoparticles: classes, properties, synthesis mechanisms, characterization, and applications. Chem. Rev., 112:2373-2433.

Giraldo, J.P.; Landry, M.P.; Faltermeier, S.M.; McNicholas, T.P.; Iverson, N.M. and Boghossian, A. A. (2014). Plant nanobionics approach to augment photosynthesis and biochemical sensing. Nat. Mater., 13:400-408.

Giraldo, J.P.; Wu, H. and Newkirk, G.M. (2019). Nanobiotechnology approaches for engineering smart plant sensors. Nat. Nanotechnol., 14:541553.

Hofmann, T.; Lowry, G.V.; Ghoshal, S.; Tufenkji, N.; Brambilla, D. and Dutcher, J.R. (2020). Technology readiness and overcoming barriers to sustainably implement nanotechnology-enabled plant agriculture. Nat. Food., 1:416-425.

Jeevanandam, J.; Barhoum, A.; Chan, Y.S.; Dufresne, A. and Danquah, M.K. (2018). Review on nanoparticles and nanostructured materials: History, sources, toxicity and regulations. Beilstein J. Nanotechnol., 9:1050-1074. 
Khan, M.N.; Mobin, M.; Abbas, Z.K.; AlMutairi, K.A. and Siddiqui, Z.H. (2017). Role of nanomaterials in plants under challenging environments. Plant Physiol. Biochem., 110:194-209.

Lattanzio, V.M.T.; and Nivarlet, N. (2017). Multiplex dipstick immunoassay for semiquantitative determination of fusarium mycotoxins in Oat Methods Mol. Biol., 1536:137-142.

Lau, H.Y.; Wu, H.; Wee, E.J.H.; Trau, M.; Wang, Y. and Botella, J.R. (2017). Specific and sensitive isothermal electrochemical biosensor for plant pathogen DNA detection with colloidal gold nanoparticles as probes. Sci. Rep., 7:38896.

Mitter, N.; Worrall, E.A.; Robinson, K.E., Li, P.; Jain, R.G. and Taochy, C. (2017). Clay nanosheets for topical delivery of RNAi for sustained protection against plant viruses. Nat. Plants., 3:16207

Molina, M.; Asadian-Birjand, M.; Balach, J.; Bergueiro, J.; Miceli, E. and Calderón, M. (2015). Stimuli-responsive nanogel composites and their application in nanomedicine. Chem. Soc. Rev., 44:6161-6186.

Nath, S.; Kaittanis, C.; Tinkham, A. and Perez, J.M. (2008). Dextran-coated gold nanoparticles for the assessment of antimicrobial susceptibility. Anal. Chem., 80:1033-1038.

Rai, V.; Acharya, S. and Dey, N. (2012). Implications of nanobiosensors in agriculture. J. Biomater. Nanobiotechnol., 03:315-324.

Roduner, E. (2006). Size matters: Why nanomaterials are different. Chem Soc. Rev., 35:583-592.

Sanzari, I., Leone, A. and Ambrosone, A. (2019). Nanotechnology in plan science: To make a long story short. Front. Bioeng. Biotechnol., 7:120.
Torney, F.; Trewyn, B.G.; Lin, V.S.Y. and Wang, K. (2007). Mesoporous silica nanoparticles deliver DNA and chemicals into plants. Nat. Nanotechnol., 2:295-300.

Valenstein, J.S., Lin, V.S.Y.; Lyznik, L.A.; Martin-Ortigosa, S.; Wang, K. and Peterson, D.J. (2013). Mesoporous silica nanoparticle-mediated intracellular cre protein delivery for maize genome editing via loxP site excision. Plant Physiol., 164:537-547.

Wang, P.; Lombi, E.; Zhao, F.J. and Kopittke, P.M. (2016). Nanotechnology: A new opportunity in plant sciences. Trends Plant Sci., 21:699-712.

Wang, F.; Li, K.; and Shi, Z. (2020). Phosphorus fertilization and mycorrhizal colonization change silver nanoparticle impacts on maize. Ecotoxicol., 30:118-129.

Wang, J.W.; Grandio, E.G.; Newkirk, G.M.; Demirer, G.S., Butrus, S. and Giraldo, J. P. (2019). Nanoparticle-mediated genetic engineering of plants. Mol. Plant, 12:1037-1040.

War, J.M.; Fazili, M.A.; Mushtaq, W.;Wani, A.H. and Bhat, M.Y. (2020) Role of nanotechnology in crop improvement. In: Hakeem K., Pirzadah T. (eds) Nanobiotechnology in Agriculture. Nanotechnology in the Life Sciences. Springer, Cham. https://doi.org/10.1007/978-3-03039978-8_4.

Yao, K.S.; Li, S.J.; Tzeng, K.C.; Cheng, T.C.; Chang, C.Y. and Chiu, C.Y. (2009). Fluorescence silica nanoprobe as a biomarker for rapid detection of plant pathogens. Adv. Mater. Res., 79:513-516.

Zhao, X.; Meng, Z; Wang, Y.; Chen, W.; Sun, C.; Cui.; B, Cui, J.; Yu, M.; Zeng, Z; Guo, S.; Luo, D.; Cheng, J.Q.; Zhang, R. and Cui, H. (2017). Pollen magnetofection for genetic modification with magnetic nanoparticles as gene carriers. Nat. Plants, 3(12):956-964. 